\title{
KONTRIBUSI KONSEP DIRI DAN KEMATANGAN EMOSI TERHADAP PENYESUAIAN DIRI SISWA DAN IMPLIKASINYA DALAM BIMBINGAN DAN KONSELING
}

\author{
Marimbuni $^{1}$ \\ Syahniar $^{2}$ \\ Riska Ahmad ${ }^{3}$
}

\begin{abstract}
Abstrak
Penelitian ini dilakukan untuk melihat kemampuan siswa untuk berpidato di sekolah. Konsep diri dan kematangan emosi adalah dua faktor penting dalam penyesuaian diri. Penelitian ini bertujuan untuk mendeskripsikan: 1) konsep diri, 2) kematangan emosi, dan 3) penyesuaian diri serta penyesuaian diri, 5) kontribusi kematangan emosi terhadap penyesuaian diri, dan 6) kontribusi dari Baik konsep diri dan kematangan emosi terhadap penyesuaian diri. Penelitian yang digunakan adalah 148 siswa SMP Pesantren Modern Terpadu (PMT) Prof. Dr. Hamka. 100 di antaranya dipilih sebagai sampel penelitian dengan menggunakan teknik proportional stratified random sampling. Instrumen yang digunakan adalah model Skala Likert. Hasil uji validitas instrumen konsep sendiri adalah 0,475. Sementara itu, hasil uji validitas instrumen kematangan emosi adalah 0,517 dan hasil uji validitas instrumen penyesuaian diri adalah 0,533. Hasil uji reliabilitas instrumen konsep diri adalah 0,834 dan hasil uji reliabilitas instrumen kematangan emosi adalah 0,858 , Akhirnya, hasil uji reliabilitas instrumen penyesuaian diri adalah 0,852. Data dianalisis dengan menggunakan statistik deskriptif, regresi sederhana, dan regresi berganda. Hasil analisis data menunjukkan bahwa: 1) konsep diri diri adalah dalam kategori positif, 2) kontribusi konsep diri terhadap penyesuaian diri sekitar 26,5\%,5) distribusi kematangan emosional terhadap penyesuaian diri sekitar $25,2 \%$, dan 6) kontribusi dari kedua self-consept dan kematangan emosional terhadap self self adjesment sekitar 35,2\%. Implikasi dari penelitian ini dapat digunakan sebagai program bimbingan akhir bimbingan di SMP Pesantren Modern Terpadu (PMT) Prof. Dr. Hamka.
\end{abstract}

Kata Kunci: Konsep Diri, Kematangan Emosi, Penyesuaian Diri

\section{Abstract}

This research was done due to student's abilities to adjudst at school. The self concept and emotion maturity are two important factors in self adjustment. The research aimed at describeng: 1) the self concept, 2) the emotion maturity, and 3) the self adjustment as well as measuring: 4) the contribution of self concept toward self adjustment, 5) the contribution of emotion maturity toward self adjustment, and 6) the contribution of both self concept and emotion maturity towards self adjustment. The research used the population was all 134 students of SMP Pesantren Modern Terpadu (PMT) Prof. Dr. Hamka. 100 of them was chosen as the sample of the research by using the proportional stratified random sampling technique. The instrument used was the Likert model Scale. The result of the self concept instrumen 't validity test was 0.475 . meanwhile, the result of the emotion maturity

\footnotetext{
${ }^{1}$ Mahasiswa Program Studi Bimbingan dan Konseling, Universitas Negeri Padang

2 Dosen Program Studi Bimbingan dan Konseling, Universitas Negeri Padang

3 Dosen Program Studi Bimbingan dan Konseling, Universitas Negeri Padang
} 


\begin{abstract}
instrument's validity test was 0.517 and the result of the self adjustment instrument's validity test was 0.533 . The result of the self concept's instrument's reliability test was 0.834 and the result of the emotion maturity instrument's reliability test was 0.858 , Finally, the result of the self adjustment instrument's reliability test was 0.852 . The data were analyzed by using descriptive statistic, simple regression, and double regression. The result of data analysis showed that: 1) the self concept was in the positive category, 2) the contribution of self concept toward self adjustment was about $26.5 \%$, 5) thecontribution of emotional maturity toward self adjustment was about 25,2\%, and 6) the contribution of both self consept and emotional maturiti toward self self adjesment was about 35,2\%. the implication of this research can be used as the analysis of students' needs to design the guidance end counseling program at SMP Pesantren Modern Terpadu (PMT) Prof. Dr. Hamka.
\end{abstract}

Keywords: Self Concept, Emotion Maturity, Self Adjustment

\section{PENDAHULUAN}

Pada masa remaja, siswa berada dalam tahap pencarian identitas diri berupa usaha untuk menjelaskan siapa dirinya, apa peranannya dalam masyarakat, dan ke mana arah hidupnya kelak (Hurlock, 1976). Selanjutnya, Hurlock (dalam Ali \& Asrori, 2004) mengemukakan salah satu tugas perkembangan yang dialami siswa adalah mencapai hubungan baru yang lebih matang dengan teman sebaya dan berusaha untuk mencapai peran sosial di lingkungannya. Siswa yang memiliki hambatan pada diri, akan mengalami masalah dan tidak mampu mencapai kebahagiaan dalam hidup. Hal ini dikarenakan, siswa tidak mampu menyesuaikan diri, baik dengan keluarga, sekolah, dan masyarakat. Oleh karena itu, bagi siswa yang mengalami masalah penyesuaian diri perlu diberikan pelayanan konseling yang memadai, agar tercapai kesesuaian antara kebutuhan diri dengan keadaan lingkungan dimana siswa berada dan berinteraksi (Willis, 2005).

Berdasarkan hasil penelitian sebelumnya, penyesuaian diri siswa terhadap program pembelajaran di SMPN 12 Padang secara keseluruhan berada dalam kategori cukup baik (Febrianti, 2011). Selanjutnya penelitian Yuniar, dkk (2005) menunjukkan setiap tahunnya $5-10 \%$ siswa SMP di Pondok Pesantren Modern Islam (PPMI) Assalam Surakarta mengalami masalah dalam proses penyesuaian diri. Masalah yang dialami siswa tersebut yaitu tidak mampu mengikuti pelajaran, tidak bisa tinggal di asrama karena tidak bisa hidup terpisah dengan orang tua, melakukan tindakan-tindakan yang melanggar aturan, dan sebagainya.

Konsep diri merupakan salah satu faktor yang mempengaruhi penyesuaian diri siswa. Hurlock (1976) mengemukakan penting bagi siswa untuk memiliki konsep diri positif, agar dapat mewujudkan rasa percaya diri dan harga diri, serta ada keyakinan terhadap kemampuan diri, sehingga siswa cenderung tampil lebih aktif dan terbuka dalam melakukan hubungan sosial dengan orang lain. Selanjutnya, Sugeng (2003) mengemukakan Konsep diri positif mengarahkan siswa memiliki kemampuan untuk dapat menyesuaikan diri dengan baik. Sebaliknya, bagi siswa dengan konsep diri rendah maka akan pesimis atau kurang yakin terhadap diri sendiri.

Berdasarkan hasil penelitian Yengimolki (2015) mengemukakan bahwa terdapat hubungan yang signifikan antara konsep diri dengan penyesuaian diri. Kematangan emosi juga merupakan faktor penentu bagi siswa untuk mampu menyesuaikan diri dengan lingkungan. Menurut Schneiders (1964) proses penyesuaian diri siswa tergantung pada tingkat kematangan emosi yang dicapai. Hurlock (1976) menjelaskan bahwa siswa yang matang secara emosi akan memiliki kontrol diri yang baik, dan mampu mengekspresikan emosi dengan tepat sesuai dengan keadaan yang 
dihadapi, sehingga lebih mampu beradaptasi karena dapat menerima beragam orang, situasi, dan memberikan reaksi yang tepat sesuai dengan tuntutan yang dihadapi.

Hal ini didukung dari hasil penelitian Susilowati (2013) bahwa terdapat hubungan yang signifikan antara kematangan emosi dengan penyesuaian diri siswa akselerasi tingkat SMP. Dari uraian tersebut, dapat diketahui bahwa siswa yang memiliki kematangan emosi akan memiliki kontrol diri yang baik, sehingga siswa lebih mampu beradaptasi dan bereaksi sesuai dengan keadaan yang dihadapi. Selanjutnya, siswa yang telah mencapai kematangan emosi, maka mampu berorientasi pada lingkungan, mampu meredam emosi dalam menghadapi masalah-masalah yang dihadapi, dapat menerima kritik dan saran dari orang lain, dapat bertanggungjawab, dan mampu beradaptasi dengan lingkungan yang baru untuk mencapai tujuan-tujuan yang diharapkan.

SMP Pesantren Modern Terpadu (PMT) Prof. Dr. Hamka merupakan sekolah yang memadukan kurikulum pendidikan nasional dengan kurikulum pesantren. Para siswa tinggal bersama di asrama yang telah disediakan, dengan mengikuti berbagai aturan dan tuntutan yang berbeda dengan sekolah lain. Siswa harus menghadapi perubahan yang terjadi pada diri sendiri dan jauh dari orangtua. Fenomena di sekolah tersebut menunjukkan bahwa tidak semua siswa bisa melakukan penyesuaian diri. Sehingga, bagi siswa yang kesulitan menyesuaikan diri akan mudah bosan, merasa tertekan, sering kelelahan, malas belajar, melanggar aturan, dan akhirnya memilih pindah/berhenti dari sekolah.

Adapun data tentang siswa yang berhenti dari sekolah SMP Pesantren Modern Terpadu (PMT) Prof. Dr. Hamka dapat dilihat pada tabel 1 berikut ini.
Tabel 1. Jumlah Siswa SMP PMT Prof. Dr. Hamka TA $2007 / 2008$

\begin{tabular}{lccl}
\hline \multirow{2}{*}{ Kelas } & \multicolumn{2}{c}{ Jumlah Siswa Masuk } & \multicolumn{1}{c}{$\begin{array}{c}\text { Jumlah } \\
\text { Siswa Keluar }\end{array}$} \\
& Juli 2007 & Juli 2008 & 22 orang \\
\hline Kelas VII & 114 & 92 & 14 orang \\
Kelas VIII & 75 & 61 & Tidak ada \\
Kelas IX & 95 & 95 & $\mathbf{3 6}$ orang \\
Total & $\mathbf{2 8 4}$ & $\mathbf{2 4 8}$ & \\
Sumber: Hanuji (2011) & &
\end{tabular}

Tabel 2. Jumlah Siswa SMP PMT Prof. Dr. Hamka TA. 2008/2009 Semester Ganjil

\begin{tabular}{|c|c|c|c|}
\hline \multirow{2}{*}{ Kelas } & \multicolumn{2}{|c|}{ Jumlah Siswa Masuk } & \multirow{2}{*}{$\begin{array}{c}\text { Jumlah } \\
\text { Siswa } \\
\text { Keluar }\end{array}$} \\
\hline & Juli 2008 & Des 2008 & \\
\hline Kelas VII & 113 & 98 & 15 orang \\
\hline Kelas VIII & 96 & 85 & 11 orang \\
\hline Kelas IX & 62 & 62 & Tidak ada \\
\hline Total & 271 & 245 & 26 orang \\
\hline
\end{tabular}

Tabel 3. Jumlah Siswa SMP PMT Prof. Dr. Hamka TA 2015/2016

\begin{tabular}{llcl}
\hline \multicolumn{1}{c}{ Kelas } & \multicolumn{2}{c}{ Jumlah Siswa Masuk } & $\begin{array}{c}\text { Jumlah } \\
\text { Siswa } \\
\text { Keluar }\end{array}$ \\
\hline Kelas VII & Juli 2015 & Des 2015 & $\begin{array}{c}\text { Tidak ada } \\
\text { Kelas VIII }\end{array}$ \\
Kelas IX & 36 & 45 & 1 orang \\
Total & 62 & 35 & 8 orang \\
Sumber: Data dari Tata Usaha SMP PMT Prof. Dr. Hamka
\end{tabular}

Tahun 2015

Berdasarkan tabel-tabel tersebut, dapat dipahami bahwa masih ada beberapa siswa yang berhenti/pindah sekolah. Terdapat beberapa alasan siswa berhenti/pindah sekolah, antara lain karena siswa tidak betah, bosan, tidak bisa jauh dari orang tua, dan sebagainya. Hal ini disebabkan karena siswa belum mampu menyesuaikan diri di lingkungan sekolahnya.

Berdasarkan fenomena di sekolah tersebut, diketahui bahwa masih ada siswa dengan konsep diri negatif mengarah pada penolakan diri, sehingga siswa cenderung mengembangkan perasaan tidak mampu, rendah diri, dan kurang percaya diri. Siswa tidak percaya diri ketika harus berpartisipasi dalam suatu aktivitas sosial dan memulai hubungan baru dengan orang lain. Penolakan diri juga dapat memicu 
munculnya sikap agresif dan perilaku negatif, sehingga siswa menjadi tertutup dan kurang tertarik untuk menjalin hubungan sosial dengan orang lain. Kematangan emosi siswa di sekolah menunjukkan siswa yang belum matang secara emosi akan mudah tersinggung, cepat marah, menyampaikan emosi yang meledak-ledak tanpa pengendalian diri.

Berdasarkan penjelasan sebelumnya, dapat diketahui bahwa konsep diri dan kematangan emosi merupakan faktor-faktor yang mempengaruhi penyesuaian diri siswa. Guru Bimbingan dan Konseling (BK) dapat berperan dapat membantu peningkatan penyesuian diri siswa di sekolah. Hal ini sesuai dengan Peraturan Menteri Pendidikan dan Kebudayaan Republik Indonesia nomor 111 tahun 2014 tentang Bimbingan dan Konseling pada Pendidikan Dasar dan Pendidikan Menengah Pasal 2, yang menyatakan salah satu fungsi layanan BK di sekolah yaitu siswa mampu melakukan penyesuaian diri dengan diri sendiri dan lingkungan. Melalui program yang telah disusun, maka guru BK dapat mengembangkan pengembangan potensi diri siswa secara optimal termasuk pengembangan konsep diri, kematangan emosi, dan penyesuaian diri.

Berdasarkan berbagai fenomena tersebut, maka peneliti tertarik melakukan penelitian dengan judul "Kontribusi Konsep Diri dan Kematangan Emosi Terhadap Penyesuaian Diri Siswa serta Implikasinya dalam Bimbingan dan Konseling”.

\section{METODOLOGI}

Penelitian ini juga menggunakan metode korelasional dan regresi ganda yang bertujuan untuk menguji kontribusi dua variabel bebas terhadap satu variabel terikat. Adapun variabel dalam penelitian ini terdiri dari konsep diri $\left(\mathrm{X}_{1}\right)$ dan kematangan emosi $\left(\mathrm{X}_{2}\right)$ yang merupakan variabel bebas, serta penyesuaian diri (Y) merupakan variabel terikat. Populasi penelitian adalah siswa kelas VII, VIII dan IX SMP PMT Prof. Dr. Hamka Padang Pariaman yang berjumlah 134 siswa, sampel berjumlah 100 siswa, yang dipilih dengan teknik proportional stratified random sampling. Instrumen yang digunakan adalah skala model Likert. Data dianalisis dengan statistik deskriptif, regresi sederhana dan ganda. Analisis data dibantu dengan menggunakan program SPSS versi 17.00 .

\section{HASIL PENELITIAN}

\section{Deskripsi Data}

Data dalam penelitian ini meliputi variabel konsep diri $\left(\mathrm{X}_{1}\right)$, kematangan emosi $\left(\mathrm{X}_{2}\right)$, dan penyesuaian diri siswa $(\mathrm{Y})$. Berikut ini dikemukakan deskripsi data hasil penelitian.

\section{Konsep Diri $\left(\mathrm{X}_{1}\right)$}

Deskripsi data konsep diri siswa dapat dilihat pada Tabel 4.

Tabel 4. Distribusi Frekuensi dan PersentaseKonsep diri

\begin{tabular}{clcc}
\hline $\begin{array}{c}\text { Skor } \\
\text { Interval }\end{array}$ & \multicolumn{1}{c}{ Kategori } & Frekuensi & \% \\
\hline$\geq 105$ & Sangat Positif & 13 & 13 \\
$85-104$ & Positif & 67 & 67 \\
$65-84$ & Cukup Positif & 20 & 20 \\
$45-64$ & Tidak Positif & 0 & 0 \\
$\leq 44$ & Sangat Tidak Positif & 0 & 0 \\
Total & & $\mathbf{1 0 0}$ & $\mathbf{1 0 0}$ \\
\hline
\end{tabular}

Tabel 4 di atas memperlihatkan bahwa sebagian besar siswa memiliki konsep diri kategori positif yaitu sebesar $67 \%$, sebagian siswa lainnya berada pada kategori sangat positif yaitu sebesar 13\%, kemudian pada kategori cukup positif sebesar 20\%. Jadi, secara rata-rata konsep diri siswa berada pada kategori positif.

\section{Kematangan Emosi $\left(\mathbf{X}_{2}\right)$}

Deskripsi data kematangan emosi siswa dapat dilihat pada Tabel 5.

Tabel 5 memperlihatkan bahwa sebagian besar siswa memiliki kematangan emosi kategori tinggi yaitu sebesar $69 \%$, pada kategori sangat tinggi sebesar $26 \%$, dan pada kategori sedang sebesar 5\%. Jadi, secara rata- 
rata kematangan emosi berada pada kategori tinggi.

Tabel 5. Distribusi Frekuensidan Persentase Kematangan Emosi

\begin{tabular}{llcc}
\hline Skor Interval & \multicolumn{1}{c}{ Kategori } & Frekuensi & \% \\
\hline$\geq 126$ & Sangat Tinggi & 26 & 26 \\
$102-125$ & Tinggi & 69 & 69 \\
$78-101$ & Sedang & 5 & 5 \\
$54-77$ & Rendah & 6 & 0 \\
$\leq 53$ & Sangat Rendah & 0 & 0 \\
& Total & $\mathbf{2 1 5}$ & $\mathbf{1 0 0}$ \\
\hline
\end{tabular}

\section{Penyesuaian Diri (Y)}

Deskripsi data penyesuaian diri siswa yang berjumlah 100 responden dapat dilihat pada Tabel 6 di bawah ini.

Tabel 6. Distribusi Frekuensidan Persentase Penyesuaian Diri Siswa

\begin{tabular}{llcc}
\hline $\begin{array}{c}\text { Skor } \\
\text { Interval }\end{array}$ & \multicolumn{1}{c}{ Kategori } & Frekuensi & \% \\
\hline$\geq 118$ & Sangat Baik & 43 & 43 \\
$94-117$ & Baik & 55 & 55 \\
$70-93$ & Cukup Baik & 2 & 2 \\
$46-69$ & Tidak Baik & 0 & 0 \\
$\leq 45$ & Sangat Tidak Baik & 0 & 0 \\
& Total & $\mathbf{1 0 0}$ & $\mathbf{1 0 0}$ \\
\hline
\end{tabular}

Tabel 6 tersebut memperlihatkan bahwa sebagian besar penyesuaian diri siswa berada pada kategori baik yaitu sebesar 55\%, pada kategori sangat baik sebesar $43 \%$, dan pada kategori cukup baik sebesar $2 \%$. Jadi, secara rata-rata penyesuaian diri siswa berada pada kategori baik.

\section{Pengujian Persyaratan Analisis Data}

Uji persyaratan analisis yang dilakukan pada data penelitian ini adalah uji normalitas, uji linieritas, dan uji multikolinieritas.

\section{Uji Normalitas}

Pengujian normalitas dilakukan dengan menggunakan metode Kolmogorov-Smirnov. Jika Asymp. Sig. atau $P$-value $>$ dari 0.05 (taraf signifikansi), maka data berasal dari populasi yang berdistribusi normal.
Berdasarkan hasil uji normalitas data, maka nilai Asymp. Sig. konsep diri sebesar 0.707, kematangan emosi sebesar 0.376, dan motivasi belajar siswa sebesar 0.576 , sehingga ketiga variabel berdistribusi normal.

\section{Uji Linieritas}

Uji linieritas dalam penelitian ini memanfaatkan program SPSS. Jika nilai $\mathrm{F}_{\text {hitung }}$ $\geq \mathrm{F}_{\text {tabel }}$,maka dinyatakan linier, dan jika nilai $\mathrm{F}_{\text {hitung }}<\mathrm{F}_{\text {tabel }}$, maka dinyatakan tidak linier (Yusuf, 2013).

Berdasarkan hasil uji linieritas, didapatkan hasil bahwa hubungan konsep diri dengan penyesuaian diri siswa adalah linier dengan $\mathrm{F}_{\text {hitung }}(35.264)>\mathrm{F}_{\text {tabel }}$ (3.94). Data hubungan kematangan emosi dengan penyesuaian diri siswa juga linier dengan $\mathrm{F}_{\text {hitung }}(33.091)>\mathrm{F}_{\text {tabel }}$ (3.94). terdapat nilai sig. $0.000 \geq 0.05$. Artinya, data setiap variabel $X$ bersifat linier.

\section{Uji Multikolinieritas}

Berdasarkan uji multikolinieritas diperoleh nilai VIF konsep diri sebesar 1.285 dan nilai VIF kematangan emosi sebesar $1.285<10$. Berdasarkan hasil tersebut dapat disimpulkan tidak terjadi multikolinieritas antara variabel konsep diri dengan kematangan emosi.

\section{Kontribusi konsep diri dan kematangan emosi terhadap penyesuaian diri siswa}

\section{Konsep Diri terhadap Penyesuaian Diri Siswa}

Hasil analisis kontribusi konsep diri terhadap penyesuaian diri siswa dapat dilihat pada Tabel 7.

Pada Tabel 7 dapat dilihat bahwa nilai $\mathrm{R}$ sebesar 0.514 yang menunjukkan koefisien korelasi antara konsep diri terhadap penyesuaian diri siswa, dengan taraf signifikan 0.000. Nilai $\mathrm{R}$ Square $\left(\mathrm{R}^{2}\right)$ sebesar 0.265 , ini berarti $26.5 \%$ variasi tinggi-rendahnya penyesuaian diri siswa dapat dijelaskan oleh konsep diri, sedangkan sisanya $73.5 \%$ dijelaskan oleh variabel lain. 
Tabel 7. Hasil Analisis Regresi Linier Sederhana dan Uji Signifikansi $X_{1}$ terhadap Y

\begin{tabular}{cccc}
\hline Model & R & R Square & Sig. \\
\hline $\mathrm{X}_{1}-\mathrm{Y}$ & 0.514 & 0.265 & 0.000 \\
\hline
\end{tabular}

\section{Kontribusi Kematangan Emosi terhadap Penyesuaian Diri Siswa}

Hasil analisis kontribusi kematangan emosi terhadap penyesuaian diri siswa dapat dilihat pada Tabel 8 di bawah ini.

Tabel 8. Hasil Analisis Regresi Linier Sederhana dan Uji Signifikansi $X_{2}$ terhadap Y

\begin{tabular}{cccc}
\hline Model & R & R Square & Sig. \\
\hline $\mathrm{X}_{2}-\mathrm{Y}$ & 0.502 & 0.252 & 0.000 \\
\hline
\end{tabular}

Pada Tabel 8 dapat dilihat bahwa nilai $\mathrm{R}$ sebesar 0.4502 yang menunjukkan koefisien korelasi antara kematangan emosi terhadap penyesuaian diri siswa, dengan taraf signifikan 0.000. Nilai R Square $\left(\mathrm{R}^{2}\right)$ sebesar 0.252 , ini berarti $25.2 \%$ variasi tinggi-rendahnya penyesuaian diri siswa dapat dijelaskan oleh kematangan emosi, sedangkan sisanya $74.8 \%$ dijelaskan oleh variabel lain.

\section{Kontribusi Konsep Diri dan Kematangan Emosi terhadap Penyesuaian Diri Siswa}

Hasil analisis kontribusi konsep diri dan kematangan emosi terhadap penyesuaian diri siswa dapat dilihat pada Tabel 9 dibawah ini.

Tabel 9. Hasil Analisis Regresi Ganda dan Uji Signifikansi $\mathrm{X}_{1}$ dan $\mathrm{X}_{2}$ terhadap $\mathrm{Y}$

\begin{tabular}{cccc}
\hline Model & R & R Square & Sig. \\
\hline $\mathrm{X}_{1}, \mathrm{X}_{2}-\mathrm{Y}$ & 0.593 & 0.352 & 0.000 \\
\hline
\end{tabular}

Pada Tabel 9 dapat dilihat bahwa nilai $\mathrm{R}$ sebesar 0.593 yang menunjukkan koefisien korelasi ganda antara konsep diri dan kematangan emosi terhadap penyesuaian diri siswa, dengan taraf signifikan 0.000 . Nilai $\mathrm{R}$ Square $\left(\mathrm{R}^{2}\right)$ sebesar 0.352 , ini berarti $35.2 \%$ variasi tinggi-rendahnya penyesuaian diri siswa dapat dijelaskan secara bersama-sama oleh konsep diri dan kematangan emosi, sedangkan sisanya $64.8 \%$ dijelaskan oleh variabel lain.

\section{PEMBAHASAN}

\section{Konsep Diri}

Hasil analisis data penelitian menunjukkan secara keseluruhan konsep diri siswa di SMP PMT Prof. Dr. Hamka pada kategori positif. Berdasarkan pengolahan data menunjukkan bahwa sebagian besar siswa memiliki konsep diri positif sebesar $67 \%$, kategori sangat positif sebesar 13\%, dan kategori cukup positif sebesar $20 \%$. Konsep diri positif yang dimiliki siswa dapat mempengaruhi penyesuaian dirinya dalam berinteraksi di lingkungan sekolah SMP PMT Prof. Dr. Hamka.

Konsep diri siswa di SMP PMT Prof. Dr. Hamka berada pada tiga kategori, yaitu sangat positif, positif, dan cukup positif. Bagi siswa yang memiliki konsep diri kategori sangat positif, maka Guru BK/Konselor dapat memberi penguatan kepada siswa untuk mempertahankan konsep diri yang telah dimilikinya. Siswa yang memiliki konsep diri kategori positif, maka Guru BK/Konselor dapat mengarahkan siswa untuk mempertahankan dan meningkatkannya. Siswa yang konsep diri kategori cukup positif, maka Guru BK/Konselor perlu memberikan perhatian khusus agar siswa mampu meningkatkan konsep dirinya.

Konsep diri bukanlah faktor bawaan sejak lahir atau keturunan, akan tetapi dapat dibentuk dari pengalaman siswa dalam menjalin hubungan dengan orang lain. Siswa merespons akan stimulus yang diberikan orang lain yang dijadikan persepsi dalam menilai dan memandang dirinya. Konsep diri akan mempengaruhi hubungan sosial. Artinya, siswa yang memiliki konsep diri positif akan mudah melibatkan diri pada kegiatan sosial, berani berpendapat, mengeluarkan ide-ide, dan menerima saran orang lain. Sebaliknya siswa yang memiliki konsep diri negatif akan ragu-ragu dalam mengikuti kegiatan sosial, kurang percaya diri, merasa minder, khawatir mendapat kritikan, sehingga menjadikan siswa lebih tertutup. 
Berbagai upaya dapat dilaksanakan oleh Guru BK/Konselor dalam pelayanan BK di sekolah. Pelayanan BK yang dapat diterapkan dengan materi tentang kiat meningkatkan konsep diri melalui temuan hasil penelitian ini. Dari beberapa indikator pada penelitian terdapat indikator yang masih perlu untuk ditingkatkan supaya lebih baik dari sebelumnya, termasuk indikator daya tarik, gambaran diri, dan harga diri. Selanjutnya dilihat dari itemitem pernyataan ditemukan siswa kurang menerima diri disebabkan badan terlalu gemuk/ kurus, tidak percaya diri menjalin hubungan dengan teman, khawatir ditertawakan ketika menjelaskan materi pelajaran, tidak berani menyampaikan pendapat, dan segan meminta bantuan kepada teman. Dari beberapa indikator dan item pernyataan yang ditemukan, maka Guru BK dapat membuat materi layanan terkait dengan hasil temuan penelitian.

Dari berbagai temuan di atas, maka Guru BK dapat menyusun program dengan materimateri yang berkaitan dengan indikator yang telah ditemukan. Selanjutnya Guru BK dapat melaksanakannya dengan berbagai jenis layanan, seperti layanan informasi, bimbingan kelompok dan lain sebagainya.

\section{Kematangan Emosi}

Hasil analisis data penelitian menunjukkan secara keseluruhan kematangan emosi berada dalam kategori tinggi. Berdasarkan pengolahan data menunjukkan bahwa kematangan emosi siswa dalam kategori tinggi yaitu sebesar $69 \%$, kategori sangat tinggi sebesar $26 \%$, dan pada kategori sedang sebesar 5\%. Kematangan emosi yang dimiliki siswa dapat mempengaruhi penyesuaian dirinya dalam berinteraksi dengan lingkungan sekitar.

Siswa yang matang secara emosi akan mampu mengekspresikan, mengontrol, dan mengendalikan emosi secara baik, sehingga menunjukkan suatu kesiapan dalam bertindak. Siswa yang memiliki kematangan emosi yang tinggi berarti dapat memahami dan menanggapi suatu situasi dengan baik dan objektif. Oleh karena itu, Guru BK/Konselor mempunyai peranan penting dalam meningkatkan kematangan emosi siswa ke arah yang lebih baik, agar siswa mampu menyesuaikan diri dengan lingkungan secara tepat sesuai dengan norma yang berlaku.

Kematangan emosi siswa di SMP PMT Prof. Dr. Hamka berada pada tiga kategori, yaitu sangat tinggi, tinggi, dan cukup tinggi. Bagi siswa yang memiliki kematangan kategori sangat tinggi, maka Guru BK/Konselor dapat memberi penguatan untuk mempertahankan kematangan emosi yang telah dimiliki. Bagi siswa yang tergolong dalam kematangan emosi kategori tinggi, maka Guru BK/Konselor dapat mengarahkan siswa untuk mempertahankan dan meningkatkan kematangan emosi kepada yang lebih baik. Bagi siswa yang memiliki kematangan emosi kategori cukup tinggi, maka Guru BK/Konselor perlu memberikan berbagai materi yang membuat siswa mampu meningkatkan kematangan emosi yang dimilikinya.

Guru BK/Konselor dapat menyampaikan berbagai materi dalam pelayanan BK di sekolah agar siswa memiliki kematangan emosi yang tinggi. Dari beberapa indikator penelitian terdapat indikator yang masih perlu untuk ditingkatkan supaya lebih baik dari sebelumnya, termasuk indikator bersifat terbuka dan mengelola emosi. Selanjutnya dilihat dari item-item pernyataan ditemukan bahwa siswa masih tertutup kepada teman dan tidak mau terbuka kepada teman-temannya, selain itu juga ditemukan pada indikator mengelola emosi bahwa siswa mengeluarkan kata-kata yang kurang baik ketika marah. Artinya siswa belum mampu mengontrol diri ketika emosi. Oleh karena itu, Guru BK/ Konselor dapat memberikan materi yang berkaitan dengan temuan pada penelitian ini, materi itu dapat diberikan oleh Guru BK/ Konselor melalui layanan.

\section{Penyesuaian Diri}

Hasil analisis data penelitian menunjukkan secara keseluruhan penyesuaian diri siswa berada pada kategori baik yaitu sebesar $55 \%$, kategori sangat baik sebesar $43 \%$, dan 
kategori cukup baik sebesar $2 \%$. Kemampuan penyesuaian diri siswa merupakan kunci keberhasilan siswa dalam berinteraksi dengan lingkungan sosialnya

Penyesuaian diri siswa di SMP PMT Prof. Dr. Hamka berada pada tiga kategori, yaitu sangat baik, baik, dan cukup baik. Bagi siswa yang tergolong dalam penyesuaian diri kategori sangat baik, maka Guru BK/Konselor dapat memberi penguatan kepada siswa untuk mempertahankannya.

Menurut Fatimah (2010), upaya yang dapat dilakukan untuk memperlancar proses penyesuaian diri siswa di sekolah yaitu (a) menciptakan situasi sekolah yang dapat menimbulkan rasa betah kepada siswa, baik secara sosial, fisik, maupun akademik, (b) menciptakan suasana belajar mengajar yang menyenangkan bagi siswa, (c) berusaha memahami siswa secara menyeluruh, baik prestasi belajar, sosial, maupun aspek pribadinya, (d) menggunakan metode dan alat mengajar yang mendorong gairah belajar, (e) menggunakan prosedur evaluasi yang dapat memperbesar motivasi belajar, (f) menciptakan ruangan kelas yang memenuhi syarat kesehatan, (g) membuat tata tertib sekolah yang jelas dan dipahami siswa, (h) adanya keteladanan dari para guru dalam segala aspek pendidikan, (i) mendapatkan kerja sama dan saling pengertian dari para guru dalam menjalankan kegiatan pendidikan, (j) melaksanakan program BK dengan sebaik-baiknya.

Bagi siswa yang tergolong penyesuaian diri kategori yang baik, maka Guru BK/Konselor dapat mengarahkan siswa untuk mampu mempertahankan dan meningkatkannya. Bagi siswa yang tergolong kategori cukup baik, maka Guru BK/Konselor perlu memberikan berbagai materi yang membuat siswa untuk mampu meningkatkan kemampuan penyesuaian dirinya ke arah yang lebih baik. Dari beberapa indikator penelitian terdapat indikator yang masih perlu untuk ditingkatkan supaya lebih baik dari sebelumnya, termasuk indikator kesadaran siswa untuk mematuhi aturan sekolah, mengikuti pembelajaran di kelas, menerima teman apa adanya. Selanjutnya dilihat dari item-item pernyataan ditemukan siswa menunda mengerjakan tugas, mengerjakan hal lain ketika guru menerangkan pelajaran, dan menjelaskan materi pelajaran kepada teman yang belum mengerti.

Peran Guru BK/Konselor sangat diperlukan untuk peningkatan penyesuaian diri siswa tersebut. Hasil penelitian Yusnimar (2009) dan Febrianti (2011) mengemukakan bahwa layanan yang bisa diberikan oleh Guru BK/ Konselor dalam membantu penyesuaian diri di sekolah yaitu sebagai berikut.

\section{Layanan orientasi}

Guru BK/Konselor memperkenalkan kepada siswa tentang peraturan sekolah, fasilitas sekolah, organisasi, kegiatan ekstrakurikuler yang dapat membantu siswa pengembangan kemampuan yang dimiliki.

\section{Layanan informasi}

Guru BK/Konselor memberikan pemahaman kepada siswa terkait pengenalan lingkungan sekolah. Guru BK/Konselor dapat menyampaikan berbagai materi berkenaan pemahaman diri, mengenali kekurangan dan kelebihan diri, mengenali bakat dan minat, dan mengenali lingkungan sekolah termasuk peraturan, hak, dan kewajiban siswa di sekolah.

\section{Layanan konseling perorangan}

Guru BK/Konselor dapat melaksanakan layanan konseling perorangan kepada siswa yang mengalami masalah terkait penyesuaian dirinya di sekolah. Hal ini sebagai upaya membantu siswa mengatasi kondisi diri yang sedang KES-T dan terwujudnya kondisi KES.

\section{Layanan penempatan dan penyaluran.}

Guru BK/Konselor membantu siswa dalam mengatur tempat duduk sesuai dengan kondisi fisik siswa dan membantu memilih kegiatan ekstrakurikuler yang tepat sesuai dengan bakat dan minat. 


\section{Layanan bimbingan kelompok}

Guru BK/Konselor mengajak siswa membahas topik-topik umum tentang bagaimana mengembangkan motivasi dan sikap positif dan lain sebagainya. Hal ini didukung penelitian yang dilakukan Yanizon (2012), bahwa layanan bimbingan kelompok efektif meningkatkan penyesuaian diri siswa.

Berdasarkan uraian tersebut, dapat diketahui layanan orientasi, informasi, konseling perorangan, penempatan dan penyaluran, dan bimbingan kelompok yang dapat dilaksanakan Guru BK/Konselor dalam membantu siswa untuk menyesuaikan diri di sekolah. Selanjutnya Guru $\mathrm{BK} /$ Konselor dapat membuat program layanan dengan materi-materi yang berkaitan dengan temuan penelitian ini.

\section{Kontribusi Konsep Diri terhadap Penyesuaian Diri Siswa}

Hasil penelitian menunjukkan bahwa konsep diri berkontribusi secara signifikan terhadap penyesuaian diri siswa. Temuan ini diperoleh berdasarkan rangkaian analisis data bahwa koefisien korelasi sebesar 0.257. Menurut Hasan (2010) koefisien korelasi tersebut pada tarap cukup berarti dan koefisien determinasi (R Squere) konsep diri terhadap penyesuaian diri siswa sebesar 0.265. Artinya, kontribusi variabel konsep diri terhadap penyesuaian diri siswa $26.5 \%$, sedangkan sisanya (100\%$26.5 \%=73.5 \%$ ) dijelaskan variabel lain. Hal ini menunjukkan bahwa konsep diri merupakan salah satu faktor yang berkontribusi terhadap penyesuaian diri siswa.

Konsep diri yang positif akan mengarahkan siswa berperilaku aktif secara baik dalam berinteraksi dengan orang lain. Hal ini dikarenakan, siswa yang memiliki konsep diri secara positif mampu menerima kondisi diri apa adanya dan merespons orang lain dengan baik. Sebaliknya, siswa yang memiliki konsep diri yang negatif dapat mengalami kesulitan dalam berinteraksi dengan orang lain. Hal ini dikarenakan, siswa yang konsep diri negatif sering memandang dunia dengan pesimis yang berlebihan, merespons kondisi secara kurang baik dan kurang menyenangi kelebihan orang lain. Oleh karena itu, penting bagi siswa untuk mengembangkan konsep diri positif, agar mampu menyesuaikan diri dengan baik.

\section{Kontribusi Kematangan Emosi terhadap Penyesuaian Diri Siswa}

Hasil penelitian menunjukkan bahwa kematangan emosi berkontribusi secara signifikan terhadap penyesuaian diri siswa. Temuan ini diperoleh berdasarkan rangkaian analisis data bahwa koefisien korelasi sebesar 0.245. Menurut Hasan (2010) koefisien korelasi tersebut pada tarap cukup berarti dan koefisien determinasi (R Square) kematangan emosi terhadap penyesuaian diri siswa sebesar 0.252 . artinya, kontribusi variabel kematangan emosi terhadap penyesuaian diri siswa sebesar $25.2 \%$, sedangkan sisanya $\quad(100 \%-25.2 \%=74.8 \%)$ dijelaskan variabel lain. Hal ini menunjukkan bahwa kematangan emosi merupakan salah satu faktor yang berkontribusi terhadap penyesuaian diri.

Berdasarkan hasil penelitian tersebut, penyesuaian diri siswa juga ditentukan oleh kematangan emosinya dalam berinteraksi dengan orang lain. Siswa yang memiliki kematangan emosi akan mudah menyesuaikan diri, sebaliknya siswa yang tidak matang secara emosi akan mengalami kendala dalam menyesuaikan diri di lingkungannya. Perkembangan dan kematangan mempunyai hubungan yang erat dengan proses penyesuaian diri, dalam arti bahwa proses penyesuaian diri banyak tergantung pada tingkat perkembangan dan kematangan yang dicapai.

\section{Kontribusi Konsep Diri dan Kematangan Emosi terhadap Penyesuaian Diri Siswa}

Hasil penelitian menunjukkan bahwa konsep diri dan kematangan emosi secara bersama-sama berkontribusi secara signifikan terhadap penyesuaian diri siswa. Temuan ini diperoleh berdasarkan rangkaian analisis data bahwa koefiensi korelasi sebesar 0.338. Menurut Hasan (2010) koefiensi tersebut pada tarap cukup berarti dan koefisien determinasi 
(R Square) konsep diri dan kematangan emosi secara bersama-sama terhadap penyesuaian diri siswa sebesar 0.352 . Artinya, kontribusi variabel konsep diri dan kematangan emosi secara bersama-sama terhadap penyesuaian diri sebesar $35.2 \%$, sedangkan sisanya (100\%$35.2 \%=74.8 \%$ ) dijelaskan variabel lain.

Berdasarkan hasil penelitian, kematangan emosi merupakan salah satu faktor yang berkontribusi terhadap penyesuaian diri siswa.

Berdasarkan rangkaian analisis yang telah dijelaskan di atas, dapat dipahami bahwa terdapat sejumlah kunci pokok dalam meningkatkan penyesuaian diri siswa, salah satunya adalah konsep diri. Hal ini disebabkan karena konsep diri merupakan faktor internal dalam penyesuaian diri.

\section{KESIMPULAN DAN SARAN}

\section{Kesimpulan}

Berdasarkan temuan dan pembahasan hasil penelitian, maka dapat dikemukakan kesimpulan sebagai berikut:

1. Secara rata-rata konsep diri Siswa SMP PMT Prof. Dr. Hamka berada pada kategori positif.

2. Secara rata-rata kematangan emosi siswa SMP PMT Prof. Dr. Hamka berada pada kategori tinggi.

3. Secara rata-rata penyesuaian diri siswa SMP PMT Prof. Dr. Hamka berada pada kategori baik.

4. Konsep diri memberikan kontribusi secara signifikan terhadap penyesuaian diri siswa SMP PMT Prof. Dr. Hamka yaitu sebesar 26.5\% Artinya, semakin positif konsep diri siswa akan semakin baik penyesuaian diri siswa.

5. Kematangan emosi memberikan kontribusi secara signifikan terhadap penyesuaian diri siswa yaitu sebesar $25.2 \%$. Artinya, semakin tinggi kematangan emosi akan semakin baik penyesuaian diri siswa.

6. Konsep diri dan kematangan diri secara bersama-sama memberikan kontribusi secara signifikan terhadap penyesuaian diri siswa yaitu sebesar 35.2\%. Artinya, semakin tinggi kontribusi konsep diri siswa dan kematangan emosi akan semakin baik penyesuaian diri siswa.

\section{Saran}

Guru BK/Konselor di sekolah dapat memasukkan materi-materi dalam menyusun program layanan BK sesuai dengan temuan penelitian terkait dengan konsep diri, kematangan emosi dan penyesuaian diri siswa. Selanjutnya, Guru BK/Konselor dapat melaksanakannya dengan layanan orientasi, informasi, konseling perorangan, penempatan dan penyaluran, dan bimbingan kelompok.

Guru Pelajaran dan Wali kamar dapat memberikan dukungan emosional (emotional support), seperti kepedulian, perhatian, dan penghargaan (esteem support), melalui ungkapan positif terhadap siswa. Selanjutnya menciptakan situasi sekolah yang dapat menimbulkan rasa betah kepada siswa, baik secara sosial, fisik, maupun akademik sehingga tercipta suasana belajar mengajar yang menyenangkan bagi siswa.

Siswa hendaknya mau memperoleh berbagai informasi yang disampaikan Guru di sekolah, dan menerapkan berbagai materi tersebut agar memiliki konsep diri yang positif, kematangan emosi yang tinggi, dan juga penyesuaian diri yang baik di sekolah. Oleh karena itu, potensi dalam diri dapat berkembang secara optimal sehingga siswa menjadi pribadi yang cerdas dalam menyikapi tantangan

Peneliti selanjutnya dapat melanjutkan penelitian lebih lanjut dan lebih luas, terkait dengan variabel konsep diri, kematangan emosi dan penyesuaian diri siswa menggunakan pendekatan kualitatif. Sehingga, hasil penelitian selanjutnya dapat memperdalam, memperjelas dan memberikan temuan yang baru.

\section{DAFTAR PUSTAKA}

Ali, M., \& Asrori, M. (2006). Psikologi Remaja: Perkembangan peserta didik. Jakarta: 
Bumi Aksara.

Fatimah, E. (2010). Psikologi Perkembangan. Bandung: Pustaka Setia.

Febrianti. (2011).’Penyesuaian Diri Siswa terhadap Program Pembelajaran di Sekolah dan Peran Guru Pembimbing (Studi pada SMPN Kota Padang) (Tesis tidak diterbitkan). Universitas Negeri Padang, Padang.

Hasan, M. I. (2010). Pokok-pokok Materi Statistik 2: Statistik inferensi. Jakarta: Bumi Aksara.

Hanuji, I. (2011). Hubungan Persepsi Siswa tentang Penerapan High-Touch oleh Wali Kamar dengan Penyesuaian Diri Siswa di Asrama serta Implikasinya dalam Bimbingan dan Konseling di SMP Pesantren Modern Terpadu Prof. Dr. Hamka Kabupaten Padang Pariaman (Tesis tidak diterbitkan). Universitas Negeri Padang, Padang.

Hurlock, E. B. (1976). Psikologi Perkembangan: Suatu pendekatan sepanjang rentang kehidupan. Jakarta: Erlangga.

Schneiders, A. (1964). Personal Adjustment and Mental Health. New York: Hoolt, Rinehart and Winston.

Sugeng, H. (2003). Perkembangan Peserta Didik. Semarang: IKIP Press.

Susilowati, E. (2013). Kematangan emosi dengan penyesuaian sosial pada siswa akselerasi tingkat SMP. Jurnal Online Psikologi, 1(2), 101-113.

Willis, S. (2005). Konseling Keluarga. Bandung: Alfabeta.

Yanizon, A. (2012). Peningkatan Penyesuaian Sosial Siswa melalui Layanan Bimbingan Kelompok (Studi Eksperimen di Madrasah Aliyah Negeri 1 Curup) (Tesis tidak diterbitkan). Universitas Negeri Padang, Padang.

Yengimolki, S. (2015). Self-Concept, Social Adjustment and Academic Achievement of Persian Students. International Review of Social Sciences and Humanities, 8(2), $50-60$.

Yuniar, M., Abidin, Z., \& Astuti, T.P. (2005).
Penyesuaian diri santri putri terhadap kehidupan pesantren: studi kualitatif pada Madrasah Takhasusiah Pondok Pesantren Modern Islam Assalam Surakarta. Jurnal Psikologi Indonesia, 2(1), 141-150.

Yusuf, A. M. (2013). Metode Penelitian Kuantitatif, Kualitatif, dan Penelitian Gabungan. Padang: UNP Press. 